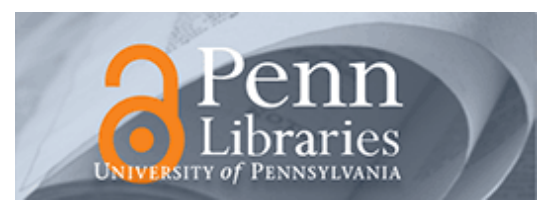

Manuscript Studies

\title{
Power Permutations in Early Hindi Manuscripts: Who Asks the Questions and Who Gives the Answers, Rāmānand or Kabīr?
}

Heide Pauwels

University of Washington

Follow this and additional works at: https://repository.upenn.edu/mss_sims

Part of the Asian History Commons, Hindu Studies Commons, and the South and Southeast Asian Languages and Societies Commons

\section{Recommended Citation}

Pauwels, Heide (2019) "Power Permutations in Early Hindi Manuscripts: Who Asks the Questions and Who Gives the Answers, Rāmānand or Kabīr?," Manuscript Studies: Vol. 4 : Iss. 1 , Article 3.

Available at: https://repository.upenn.edu/mss_sims/vol4/iss1/3 


\title{
Power Permutations in Early Hindi Manuscripts: Who Asks the Questions and Who Gives the Answers, Rāmānand or Kabīr?
}

\author{
Abstract \\ What work do manuscripts perform? How are we to understand their socio-political impact? What \\ happens when we find drastically different permutations of the same dialogical text in multiple \\ manuscripts, where the interlocutors take different positions in different versions? How do we deal with \\ that in the light of existing printed editions that intervene and "freeze" one version and marginalize \\ others? This paper focuses on how old Hindi dialogical texts fare in manuscript and print, with the case \\ study of the dialogue between the famous iconoclastic Kabīr and his purported guru the Rāma-worshiper \\ Rāmānand, as preserved in a fascinating illustrated manuscript from the beginning of the eighteenth \\ century that combines yogic and devotional texts.
}

\section{Keywords}

Manuscript studies, Old Hindi, India, Devotional texts, Rāmānand, Ramananda, Kabir, Gyan-tilak (Jnantilak), Barthwal, guru, bhakti, Hindi canon, Hindi manuscripts, philosophical dialogue 


\section{MANUSCRIPT STUDIES}

A Journal of the Schoenberg Institute for Manuscript Studies

VOLUME 4, N UMBER 1

(Spring 2019)

Manuscript Studies (ISSN 2381-5329) is published semiannually

by the University of Pennsylvania Press

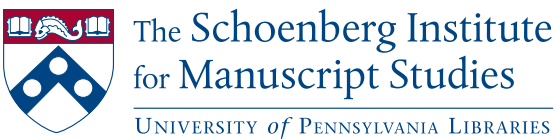




\section{Manuscript Studies, Vol. 4 [2019], Iss. 1, Art. 3}

\section{MANUSCRIPT STUDIES}

VOLUME 4, N U M B E R 1

(Spring 2019)

ISSN 2381-5329

Copyright (C) 2019 University of Pennsylvania Libraries

and University of Pennsylvania Press. All rights reserved.

Published by the University of Pennsylvania Press, 3905 Spruce Street, Philadelphia, PA 19104.

Printed in the U.S.A. on acid-free paper.

Manuscript Studies brings together scholarship from around the world and across disciplines related to the study of premodern manuscript books and documents, with a special emphasis on the role of digital technologies in advancing manuscript research. Articles for submission should be prepared according to the Chicago Manual of Style, $16^{\text {th }}$ edition, and follow the style guidelines found at http://mss.pennpress.org.

None of the contents of this journal may be reproduced without prior written consent of the University of Pennsylvania Press. Authorization to photocopy is granted by the University of Pennsylvania Press for libraries or other users registered with Copyright Clearance Center (CCC) Transaction Reporting Service, provided that all required fees are verified with CCC and paid directly to CCC, 222 Rosewood Drive, Danvers, MA 01923. This consent does not extend to other kinds of copying for general distribution, for advertising or promotional purposes, for creating new collective works, for database retrieval, or for resale.

\section{SUBSCRIPTION INFORMATION:}

Single issues: $\$ 30$

Print and online subscriptions: Individuals: $\$ 40$; Institutions: $\$ 92$; Full-time Students: $\$ 30$ International subscribers, please add $\$ 18$ per year for shipping.

Online-only subscriptions: Individuals: $\$ 32$; Institutions: $\$ 80$

Please direct all subscription orders, inquiries, requests for single issues, address changes, and other business communications to Penn Press Journals, 3905 Spruce Street, Philadelphia, PA 19104. Phone: 215-573-1295. Fax: 215-746-3636. Email: journals@pobox.upenn.edu. Prepayment is required. Orders may be charged to MasterCard, Visa, and American Express credit cards. Checks and money orders should be made payable to "University of Pennsylvania Press" and sent to the address printed directly above.

One-year subscriptions are valid January 1 through December 31. Subscriptions received after October 31 in any year become effective the following January 1. Subscribers joining midyear receive immediately copies of all issues of Manuscript Studies already in print for that year.

Postmaster: send address changes to Penn Press Journals, 3905 Spruce Street, Philadelphia, PA 19104.

Visit Manuscript Studies on the web at mss.pennpress.org. 


\section{MANUSCRIPT STUDIES}

A Journal of the Schoenberg Institute for Manuscript Studies

VOL U M 4, N U M B E R 1

\section{Articles}

In the Age of Non-Mechanical Reproduction:

Manuscript Variation in Early-Modern South Asia

Arthur Dudney, Neeraja Poddar

Manuscript Variations of Dabistān-i Maz̄āhib

and Writing Histories of Religion in Mughal India

Sudev Sheth

Power Permutations in Early Hindi Manuscripts:

Who Asks the Questions and Who Gives the Answers,

Rāmānand or Kabīr?

Heide Paunels

The Strange Afterlife of Vidyāpati Țhākura (ca. 1350-1450

CE): Anthological Manuscripts, Linguistic Confusion, and Religious Appropriation

CHRistopher L. DiAmond

Prefatory Notes on Persian Idioms of Islamic Jurisprudence:

Reasoning and Procedures of Law-Making in Premodern

Islamicate India

Naveen Kanalu

Replication and Innovation in the Folk Narratives

of Telangana: Scroll Paintings of the Padmasali

Purana, 1625-2000

Anais Da Fonseca

Nectar or Arrow: Cases of Missense Textual Mutations in Early Kabïrian Padas

Zhang Minyu 
Manuscript Studies, Vol. 4 [2019], Iss. 1, Art. 3

iv | Journal for Manuscript Studies

"Publishing" and Publics in a World Without Print:

Vernacular Manuscripts in Early Modern India

Tyler Williams

\section{Reviews}

Kay Davenport. The Bar Books: Manuscripts Illuminated for Renaud de Bar, Bishop of Metz (1303-1316).

RICHARD A. LESON

Matti Peikola, Aleksi Mäkilähde, Hanna Salmi, Mari-Liisa

Varila, and Janne Skaffari, eds. Verbal and Visual

Communication in Early English Texts.

Lydia Yaitsky KeRTZ

Alpo Honkapohja. Alchemy, Medicine, and Commercial

Book Production: A Codicological and Linguistic Study

of the Voigts-Sloane Manuscript Group.

Winston BLACK

List of Manuscripts Cited 


\title{
Power Permutations in Early Hindi Manuscripts: Who Asks the Questions and Who Gives the Answers, Rāmānand or Kabīr?
}

\author{
Heidi Pauwels \\ University of Washington
}

\section{Introduction: Canon-Freezing}

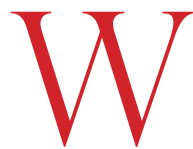

HEN Hind EMERGED AS a national language at the end of the nineteenth and the beginning of the twentieth century, one of the tasks at hand was the construction of the canon of its literature. This led to a feverish search for "Early Hindi" texts that could be pressed into service to give the language a respectable literary pedigree. ${ }^{1} \mathrm{~A}$ major role was played by Brahmin professors of Hindi at the newly founded Banaras Hindu University, first by Rāmcandra Śukla (1884-1941), who published the monumental Hind̄ Sābitya kā Itibās (Literary History of Hindi) in 1929, and later especially by Pìtāmbar Datt Baṛthvāl (1901-1944) and Hazārīprasād Dvivedī (1907-1997), who zoomed in on the "middle period"

This paper was first presented at the Annual Conference for South Asia Studies in Madison on 27 October 2017 for the panel "Social and Religious Debates in Early Hindi Narratives" organized by David Lorenzen. I am grateful to the comments from the other panelists and the audience at that occasion as well as comments on the first draft by Monika Horstmann and Peter Friedlander. I am also grateful to the Wellcome Library in London for providing the high-resolution images reproduced here.

1 For this complex process, the classical study is Christopher King, One Language, Two Scripts: The Hindi Movement in Nineteenth-Century North India (New Delhi: Oxford University Press, 1994). 
Manuscript Studies, Vol. 4 [2019], Iss. 1, Art. 3

of devotional literature (bhakti). ${ }^{2}$ They published editions of what they deemed to be seminal texts on the basis of the thousands of manuscripts amassed by organizations for the promotion of Hindi, such as the Nàgarī Pracārin̄ī Sabhā in Benares.

The selection process of what did and what did not make it into the canon was deeply influenced by the rising tide of nationalism and communalism. ${ }^{3}$ In the process, some manuscripts were favored and their texts were "frozen" in print, whereas others were marginalized. Further "freezing" happened during the transcription process: as Hindi manuscripts were prepared for the printed page, significant decisions had to be made to resolve ambiguities in the original. In manuscripts, the words are typically not separated from each other, and alternate word breaks are frequently a possibility; punctuation is missing or random, which leads to different interpretations in what constitutes a line, what is meta-textual (such as stage directions), and what is not. To make things more complicated, Hindi orthography was not yet fixed in the manuscripts. For instance, short, unstressed vowels might be rendered interchangeably as $-a^{-},-i-$, or $-u^{-}$, and long or short vowels of the same type might be interchangeable, such as $-a-$ for $-\bar{a}-$ and vice versa. This leads to considerable ambiguity in cases of minimal pairs, such as Rāma (the male God) and Rāmā (his wife). Finally, the characters used for some consonants are easily conflated with others. In short, manuscripts left their editors plenty of scope for ambiguity, misunderstanding, and overinterpretation. While we owe much to the pioneers who prepared the early editions, we should not take their work at face value. Given the nationalist context in which the editing took place, it is imperative to return to the manuscripts to form a historically informed view of the evolution of

2 For nirguna bbakti literature in print, including more popular publications, see Francesca Orsini, "Booklets and Saints: Religious Publics and Literary History," South Asia: Journal of South Asian Studies, 38, no. 3 (2015): 435-49. For a clear overview of the different publics for Kabīr specifically, see Peter Friedlander, "Kabir and the Print Sphere: Negotiating Identity," Thesis Eleven 113, no. 1 (2012): 45-56.

3 "Communalism" refers to the hardening of ethno-religious identities to the point of violent conflict, in particular between Hindus and Muslims. For the influence of print, see also Francesca Orsini, The Hindi Public Sphere, 1920-1940 (New Delhi: Oxford University Press, 2002). 


\section{Pauwels: Power Permutations in Early Hindi Manuscripts}

the texts pre-print. The purpose of this article is to demonstrate the importance of gaining this perspective by "defrosting" one such text and bringing some of its alter-ego manuscripts back into view.

Bringing fluidity back into foundational texts is particularly important for those that belong to the genre of religious debate. These texts, with titles including words like samvvād (dialogue), milan (meeting), goșthī (gathering), or bodb (enlightenment), often present two sides of an issue to establish an authoritative position. Once printed, a hierarchy is firmly established between the two: the challenger and the defendant, even where the manuscript tradition allows for multiple outcomes in different recensions. If the printed version is without investigation accepted as representing the final or even only one, alternative voices are silenced and the diversity of the tradition is lost, as is historical breadth. Revisiting the manuscripts also provides an opportunity to reflect on the materiality of how debates were remembered, as well as what indications of performative aspects of the dialogical texts can be revealed behind what is preserved on the printed page.

\section{A Dialogue Between a Strident Student, Kabir, and His Purported Guru, Rāmānand}

This article seeks to jump-start a broader "defrosting" by puzzling together a few pieces of the transmission history of one such debate that is crucial for understanding the prevalent role of Rāma devotion in contemporary India. It studies a dialogue between the popular iconoclastic Early Hindi poet Kabīr of Benares (possible fl. 1450-1500) and the man purported to be his guru, the mysterious Rāmānand. ${ }^{4}$ Very little is known with certainty about the latter, and interpretations of his life, including his date and significance, differ substantially according to different sects. Still, numerous

4 Kabīr's dates have been much debated; for a summary of the argumentation, see David N. Lorenzen, Kabir Legends and Ananta-das's Kabir Parachai (Albany: State University of New York Press, 1991), 9-18. 
contemporary devotees of the god Rāma trace their spiritual lineage to him, seeing themselves as members of the Rāmānand-sampradāy. Many also hold that notwithstanding his being a high-born Brahmin devotee of Rāma, Rāmānand initiated in the sect many low-borns, including the weaver Kabīr, who insisted that his god was nirguna - that is, beyond human traits, not limited to the Rāma of the Brahminical stories. The link between Kabīr and Rāmānand has been a central point in the research of the overwhelmingly high-caste Hindī canon-maker scholars, which in turn has drawn strong criticism from low castes, who see it as an attempt to Brahminize Kabīr. ${ }^{5}$ This is not merely an academic issue; at stake is nothing less than whether the transformative experiences on offer in Kabīr's poetry can or should be considered to be rooted in Brahminical orthodoxy.

Incongruent as the assertion of the initiation may be, it has been around for at least four centuries, and it has been accepted by many followers of Kabīr. The first evidence dates from around 1600, about a century after what can roughly be surmised to be Kabīr's date of death, and unsurprisingly within circles of the Rāmānand-sampradāy. Two Rāmānandī hagiographers figure importantly. First, the hagiographer Nābhādās included Kabīr in a list of disciples of Rāmānand in his influential listing of "who's who in the universe of devotion," or Bhakt-māl. ${ }^{6}$ Around the same time, his junior colleague Anantdās expanded upon the legends circulating about Kabīr in his Kabīr-parcaī, which features the story of his initiation by Rāmānand, at least in some (later attested) versions of the text that were preserved by one sect outside the Rāmānandī fold (the Nirañjanīs). ${ }^{7}$ As the story goes, since

5 For Dvivedî's views on Kabīr, see Monika Horstmann, "Hazārīprasād Dvivedī’s Kabīr," in Images of Kabīr, ed. M. Horstmann (New Delhi: Manohar, 2002), 115-26. For a strident denouncement of Dvivedīs appropriation, see Dharmvir, "Complete Eclipse of the Sun: Dwivedi's Kabir," Hindi: Language, Discourse, Writing: A Quarterly Journal of Mabatma Gandhi International Hindi University 1 (2000): 188-207.

6 See William Pinch, "History, Devotion, and the Search for Nabhadas of Galta," in Invoking the Past: The Uses of History in South Asia, ed. Daud Ali (Delhi: Oxford University Press, 1999), 367-99.

7 Kabīr-parcaī is studied and translated by Lorenzen in Kabir Legends, 23-42, 93-128. For the manuscript evidence, see Lorenzen, Kabir Legends, 73-91, and compare with Winand 


\section{Pauwels: Power Permutations in Early Hindi Manuscripts}

Kabīr was of low caste, he had to resort to stratagem to receive the sacred mantra from the Brahmin guru's mouth if he wanted to legitimize his practice of devotion. So he tricked Rāmānand by lying in the darkness on the chosen guru's path, as the latter was on his way to take his sacred bath in the Ganges early in the morning, descending the stairs toward the river in Benares. When he stumbled over the low-caste weaver, the surprised Brahmin uttered an exclamation “Rām!” (“My God!”), which Kabīr took as an initiation with the holy mantra of the sect. When Rāmānand later challenged him that such is not sufficient to become a devotee, Kabīr insisted on its validity, asserting in one recension of the text:

If the guru and God [Govinda] show favor and one meets the true guru, nothing is difficult. Everything is easy and spontaneous [sabaja]. This is what all the holy men say. Show yourself, Master, Give me your darshan. If you don't give it, I will weep and die. ${ }^{8}$

Rāmānand relented and recognized Kabīr as his disciple, so the story goes. These Rāmānandī hagiographers' view of things represents Kabīr as upwardly mobile and somewhat grudgingly acknowledges a mostly formal "membership" of Kabīr in their group. It is important to note that this falls well short of the "transformative experience" twentieth-century high-caste scholarship imagines the meeting with Rāmānand had for Kabīr, for which, it should be said, there is little corroboration in Kabī's own work. ${ }^{9}$ We might add that Kabir soon overshadowed his guru in popularity, to the point that we have to search to find works attributed to Rāmānand, while Kabīr's verses are included in numerous anthologies and manuscripts and remain perennially in print. In that light the Rāmānandīs stood to gain much by the association with Kabīr, and historians convincingly argue the

Callewaert and Swapna Sharma, The Hagiographies of Anantadās (London: Curzon, 2000), esp. 1-27, 43-98.

8 Translation from Lorenzen, Kabir Legends, 95; text on 134, vv. 14-15, but this is missing in most manuscripts; compare with Callewaert and Sharma, Hagiograpbies, 58.

9 See Horstmann, "Hazārīprasād Dvivedī’s Kabīr," 115-26. 
Manuscript Studies, Vol. 4 [2019], Iss. 1, Art. 3

Pauwels, Power Permutations in Early Hindi Manuscripts

story was a sectarian move around 1600 to coopt Kabīr's appeal to lowercaste bhaktas for the Rāmānand-sampradāy. ${ }^{10}$

Those who believe that these two grand devotees were close would naturally want to eavesdrop on their conversations. What kind of philosophical debates would they have conducted? Did they influence one another? Could Kabīr's nirguna view have been reconciled with Rāmānand's Rāma devotion? ${ }^{11}$ Sure enough, a dialogue, often entitled Gyān-tilak or Jũān-tilak (Mark of Wisdom), has been circulating in several versions, at least since the eighteenth century, in both Kabīr Panthī and saguna cirlces. ${ }^{12}$ I want to draw

10 First suggested by Richard Burghart, then elaborated by William Pinch in his magisterial Peasants and Monks in British India (Berkeley: University of California Press, 1996), esp. chapter 2 .

11 Not just that, but identification of Kabīr with Rāma is a strong preoccupation of the influential Mahant of the Kabīr Chaura Math in Benares, Gañgārām Śāstrī (David Swain, "Transformations in Kabīr Hagiography: Pre-modern to Modern Texts," in Studies in Early Modern Indo-Aryan Languages, Literature and Culture [New Delhi: Manohar, 1999], 398-401).

12 David Lorenzen, in A Catalog of Manuscripts in the Kabir Chaura Monastery (Mexico City: El Colegio de México, 1994), located three similar texts in manuscript 014 dated 1801 (1858 VS) (pp. 301a-308a under the name kabìr rāmanand pratham milan kī gosțhī, 349a-351b under kabìr-rāmānand ki goșthī, and 351b-355a under Jñān-tilak), and additionally in manuscripts 019, dated 1866 (1923 VS) (pp. 0b-10a), and 023, dated 1774 (1831 VS) (pp. 57b-65a). The latter are also entitled kabīr aur rāmānand kā samvōad, 062, dated 1877 (1934 VS) (pp. B167a-170b). In addition, the National Mission for Manuscripts database, Bhāratīya Kritisampada, lists the following: attributed to Kabīr in Hindi, dated 1883 (VS 1940) in the Motilal Nehru Law College, of H.S. Gaur University, Sagar, manuscript no. NS000006505 (17 fols.). The same institution has also one in Sanskrit attributed to Rāmānand, accession number 1.2 (22 fols.); there is one attributed to Rāmānand in Hindi preserved in the Śrī Tridaṇdīidev Sanskrit Shodh Sansthān, acc. no 14.6 (22 fols.), and one in Gurmukhi script in the Vishveshvarananda Vishva Bandhu Institute of Sanskrit and Indological Studies, Hoshiarpur acc. no. 265.2 (4 fols.). The same institution also has an unattributed Jñan-tilak, acc. no 2884.2 (20 fols.). An unattributed Hindi text is preserved in the Vrindavan Research Institute in Vrindaban, acc. no. 11835C (14 fols.; together in a collection with a dān-līlā and mantrayantra 11835A and B and a Jānakì-maingal written by a Mathurādās Nirmohī as 11835F), and there are two unattributed Sanskrit ones in the Sarasvatī Bhavan Library in Varanasi, manuscripts IGI000045684 (3 fols.) and IGI0000460244 (1 fol.), and another in the Nāgarī Pracārin̄ī Sabhā, dated 1894, acc. no. 2461 (3 fols.). The catalogues of the manuscripts preserved the Rajasthan Oriental Research Institute in Jodhpur (Caupasni) also give several manuscripts 


\section{Pauwels: Power Permutations in Early Hindi Manuscripts}

attention here to the earliest manuscript I am aware of, which also happens to be illustrated with a picture of the two men in conversation.

\section{An Illustrated Manuscript}

Text and image appear in an illustrated manuscript preserved, somewhat unexpectedly, in the Wellcome Collection in London, which specializes in the history of medicine. The tome made it into the collection because, as Peter Friedlander reports in his 1996 Descriptive Catalogue of the Hindi Manuscripts, it was sold as an "ancient Buddhist priest's manuscript book" that supposedly contained "magical and medical formulae . . . [and] charms." Perhaps this was due to the illustrations depicting holy men under trees, giving the impression of conveyance of botanical wisdom. Upon investigation, Friedlander points out, the volume is actually a compilation of looseleaf folios that were bound together in somewhat random sequence, the core of which consists of yogic Nāth and nirguna devotional Sant works. Although its illustrations were reproduced more than two decades ago in Friedlander's 1996 catalogue, this manuscript has attracted little scholarly attention.

The manuscript deserves to be studied in its own right for several reasons. For one, it contains several dialogical texts, between both Nāths and nirguñ $\bar{~}$ Sants. ${ }^{14}$ This makes the manuscript a rich source for studying dialogical

from the nineteenth century: vol. 1, p. 58, no. 508 (acc. no. 198 [3], which mentions Kabìr as śisya); vol. 2, p. 35, no. 564 (acc no. 1093 [5] dated 1910 VS, scribe Harīdās in Alwar); vol. 4, p. 42, no. 452 (acc. no. 4669 [14] written by the scribe Rāmdās on 8 fols.); and vol. 7, p. 79, no. 744 (acc no. 9132 [21] by the scribe Narsiṃhdās). The oldest I found reference to is from Purātan, vol. 19, pp. 80-81, no. 505 (acc. no. 34982 [9], dated 1801VS).

13 Peter Friedlander, Descriptive Catalogue of the Hindi Manuscripts in the Library of the Wellcome Institute for the History of Medicine (London: Wellcome Institute for the History of Medicine, 1996), 449. Now Wellcome Collection, MS Hindi 371.

14 The manuscript is comparable to another one from the same era that was described by Barthwal, the so-called Pauri manuscript (named after the place where it was preserved at the time, the residence of the Garhwal Pandit Tārādatt Gairolā, who in turn received it from Dr. Daljang Singh of Jaipur (see Barthwal's Traditions of Indian Mysticism Based upon Nirguna 
texts. Further, it contains many illustrations, which is rare in manuscripts of devotional works that are reckoned to belong to nirguna sampradāys or sects devoted to an abstract god. ${ }^{15}$ Whereas manuscripts with works in praise of Krishna or Rāma frequently are illustrated because storytelling of these saguna gods lends itself easily to images, this is much less the case for the nirguna counterparts. ${ }^{16}$ Furthermore, the manuscript's colophon (on fol. 188r) specifies the exact date on which the immediately preceding work was written down - in the rainy season of the year 1715 (1772 VS) — and situates the inscription of the text during the reign of the famous king Jai Singh II, founder of the city of Jaipur ( $\operatorname{Sav} \bar{a} \bar{\imath} J a i S \bar{\imath}(n) g h$ rāje). It also provides the name of the scribe, Tivādī Gokal, and the location, a sectarian center of a nirguna sect, the Dādūpanthī seat of Naraina, near Jaipur.

It is difficult to say with any certainty whether this colophon can be taken as firmly indicative for the entire manuscript, especially because the folios are not in sequence, so one cannot be sure whether the texts preceding what is now folio 188 were not written later. However, the handwriting of the colophon appears to be the same as that of Gyān-tilak. In any case, this colophon gives us a generic idea about where and when at least some of the original materials were written down. If the Gyān-tilak in the manuscript dates from this period, which seems highly likely, it is the earliest dated version that has been traced so far, a century and a half before the other known manuscripts of the work.

School of Hindi Poetry [New Delhi: Heritage Publishers, 1978], 283; he estimates it to be at least two hundred years old-that is, from ca. 1750). This manuscript also contained Nāth yogī bānīs as well as Dādūpanthī texts, in addition to a Pañc-vāṇī section at the beginning and a selection made by Rajjab at the end. Similarly, there is a manuscript dated 1714 in the Nāgarī Pracārin̄ị Sabhā (no. 1409), used by Tiwari for his Kabīr edition (see Vinay Dharwadker, Kabir: The Weaver's Songs [New Delhi: Penguin, 2003], 37).

15 On the term and how it should not be understood as oppositional to saguna, see Mukund Lath, "The Nirgun Canon in Rajasthan," in Religion, Ritual and Royalty, ed. N. K. Singh and Rajendra Joshi (Jaipur: Rawat Publications, 1999), 102-8.

16 For this point with regard to the Nāths, see Debra Diamond's introduction to a rare set of Nāth paintings from Jodhpur in the first half of the nineteenth century, as part of the catalogue Garden and Cosmos: The Royal Paintings of Jodhpur (Washington, DC: Arthur M. Sackler Gallery, 2008), 44-45. She refers to the manuscript studied here on 308 n. 33. 


\section{Pauwels: Power Permutations in Early Hindi Manuscripts}

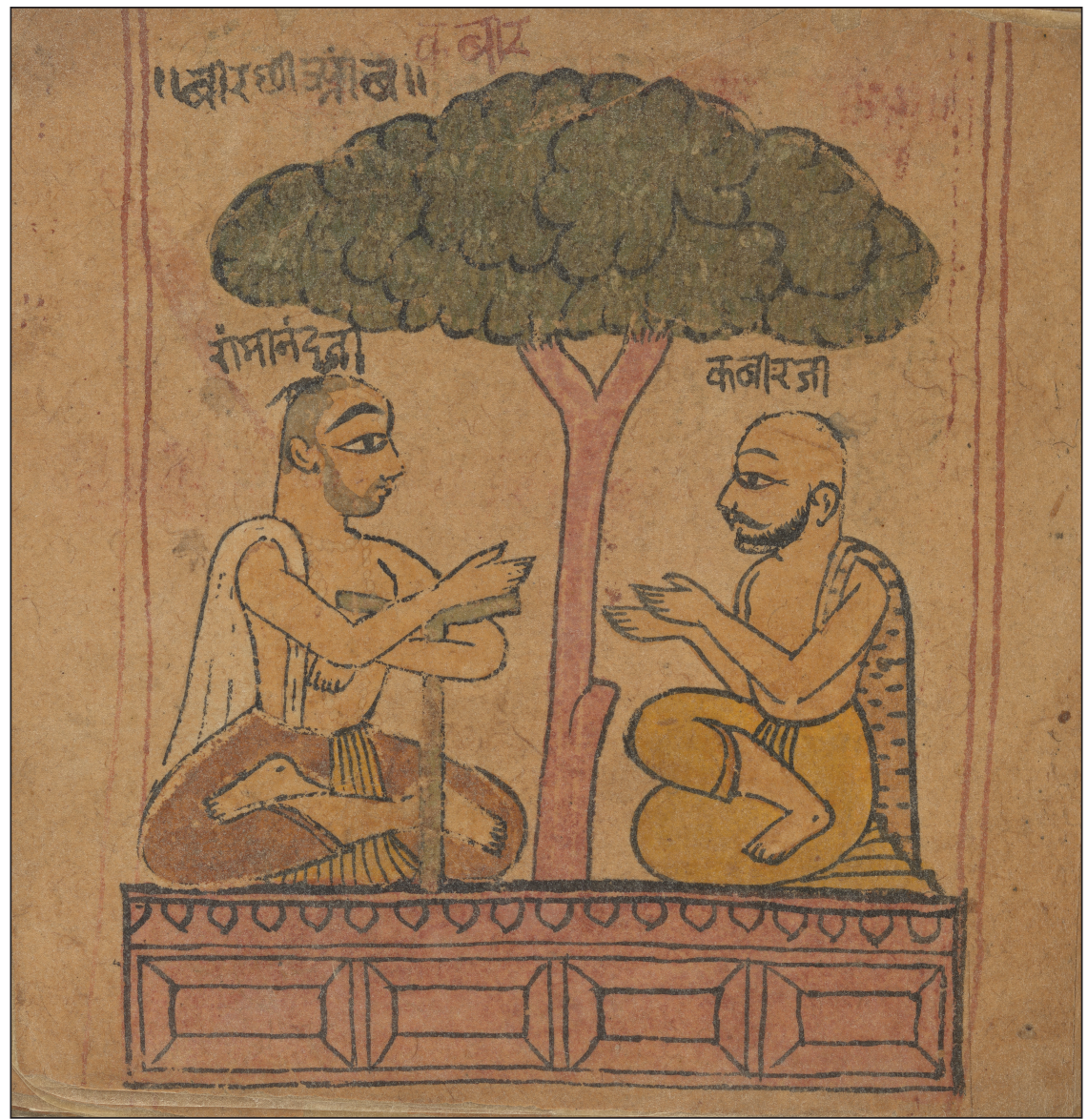

FIGURE 1. Rāmānand and Kabīr in conversation. Wellcome Collection, MS Hindi 371, fol. $150 \mathrm{v}$.

\section{The Rämānand-Kabìr Relation in the Manuscript}

The manuscript preserved in the Wellcome Collection contains a rare image of Rāmānand and Kabīr in conversation, seated under a mango tree (bīrchì āmb) (fol. 150v; fig. 1). Contrary to popular belief that Kabīr was initiated as a child or young adolescent, he is depicted as an adult with a beard. Both figures are portrayed on equal terms, as they are the same size and seated at the same level. Their hand gestures suggest an animated discussion; there is nothing to intimate a hierarchical encounter. This is in sharp contrast 
Manuscript Studies, Vol. 4 [2019], Iss. 1, Art. 3

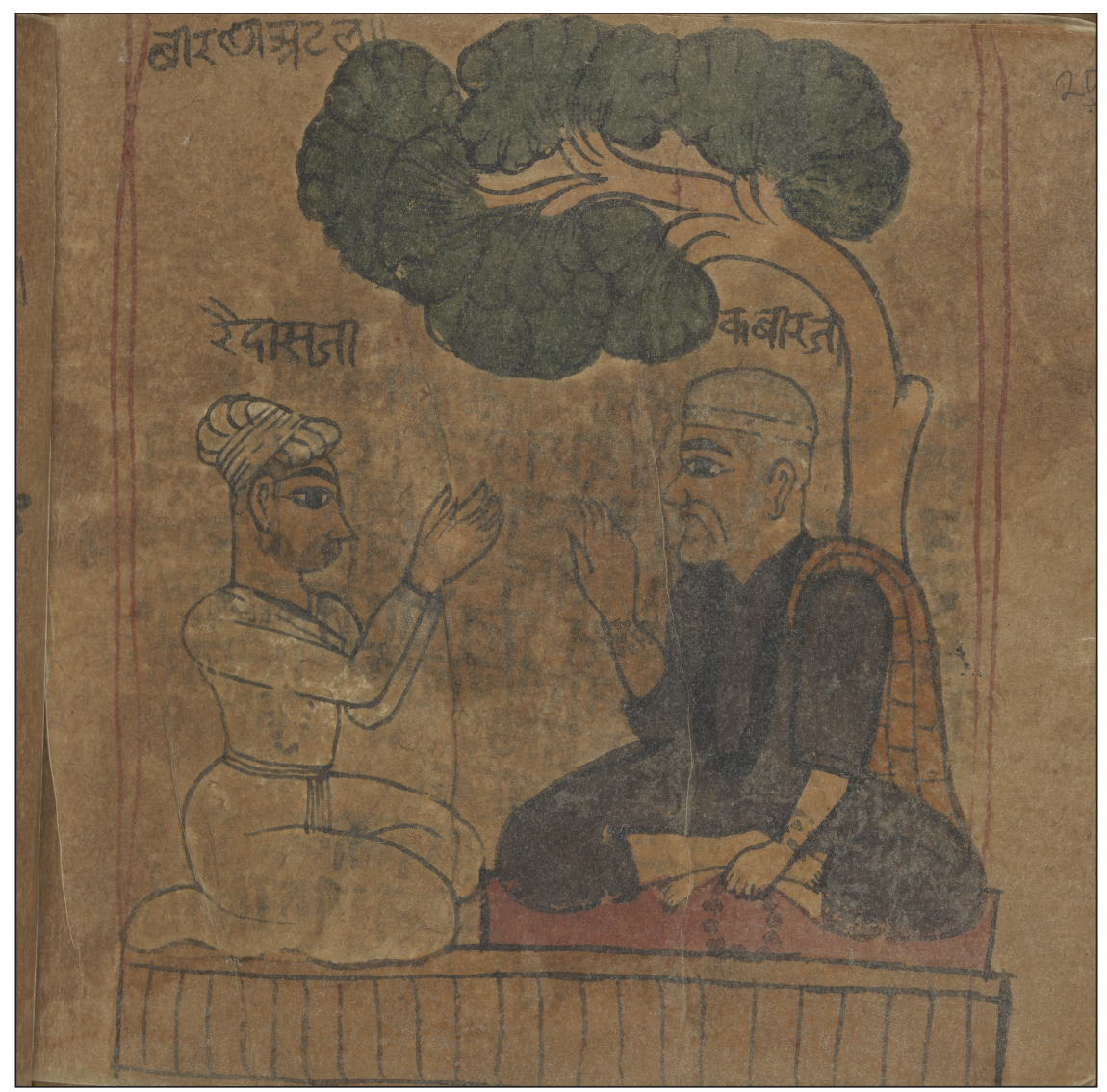

FIGURE 2. Raidās and Kabīr in conversation. Wellcome Collection, MS Hindi 371, fol. 25r.

with the depictions in the same manuscript of other gurus with their childdisciples. For instance, the image of Matsyendranāth and Gorakhnāth (fol. 136r) shows the latter clearly in a subordinate position. ${ }^{17}$ Similarly, the image of Kabīr and Raidās shows the latter with reverently folded hands in front of Kabīr (fol. 25r). ${ }^{18}$ By contrast, the image of Rāmānand and Kabīr itself seems to refute the hierarchical relationship between the two. Does the text do the same?

17 Friedlander, Descriptive Catalogue, 589.

18 Friedlander, Descriptive Catalogue, 602, fig. 2. 


\section{Pauwels: Power Permutations in Early Hindi Manuscripts}

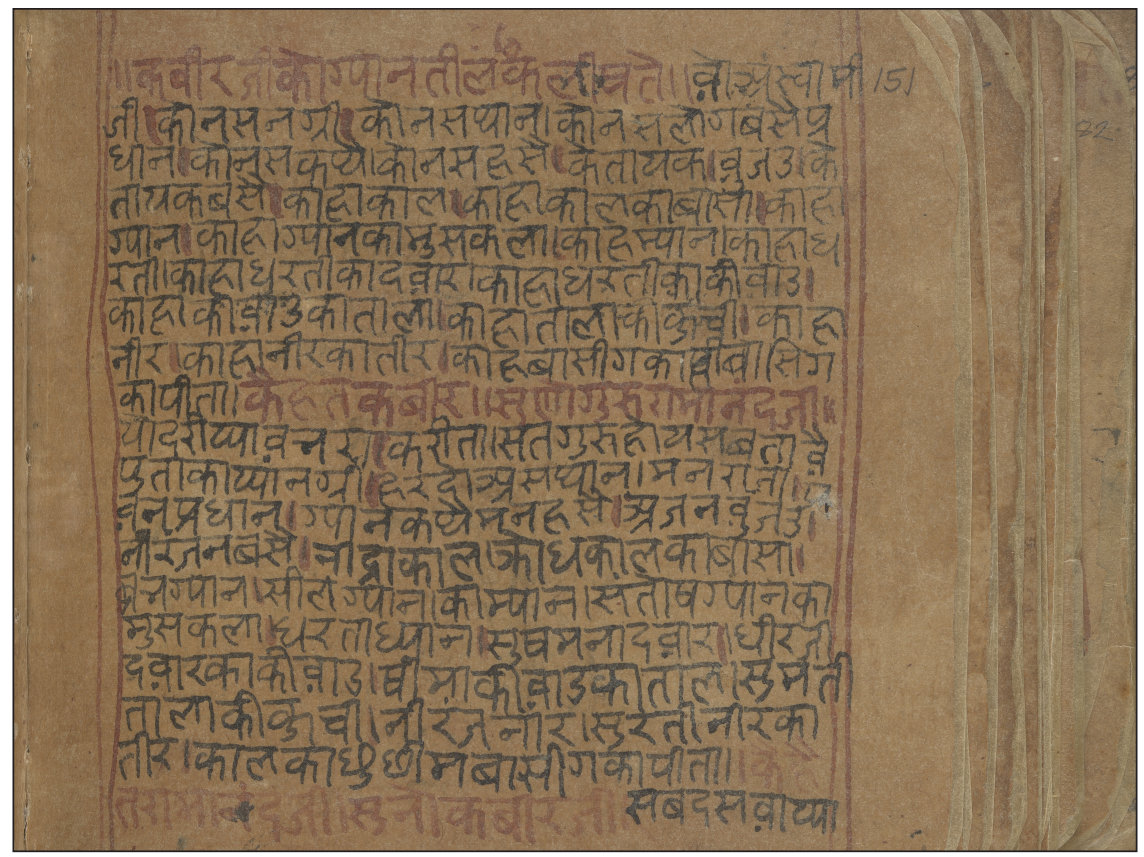

FIGURE 3. Text facing image of Rāmānand and Kabīr in conversation. Wellcome Collection, MS Hindi 371, fol. 151r.

The text facing the illustration (fol. 151r; fig. 3) is fittingly that of Gyāntilak, the conversation between Kabīr and Rāmānand. The introductory colophon, written in red ink, may be read to attribute the text to Kabir (Kabīrajī ko gyānatilaka līṣate), but the final colophon also includes Rāmānand

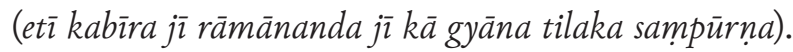

At the very beginning of the text appear the words vo asvāmijī (that Svāmī), followed by a bar in red ink. ${ }^{19}$ This seems to indicate the speaker, as it is followed with a volley of questions introduced by question words (kona [what kind], ketāyaka [how many], kāhā [what]), each separated from the next by punctuation in the Devanāgarī script: a dand da, or "bar," marked in

19 Alternatively, one could read $v o$ as a variant spelling of the syllable om. 
Manuscript Studies, Vol. 4 [2019], Iss. 1, Art. 3

red ink. This makes sense if we consider the possible performance situation in which the manuscript may have been used. Perhaps it was intended to be read out loud while pointing at the image of Rāmānand. ${ }^{20}$ The punctuation makes it clear that it is not to be taken as a vocative (also, vo is not attested as a vocative particle in Early Hindi); thus the questions are posed by, not addressed to, Rāmānand. To get some idea of the questions, here are the first few:

Kona sa nagrī, kona sa thāna

Kona sa loga basai pradhāna

Kona sa ka(m)pyai, kona sa basai

Ketāyaka vujaḍ, Ketāyaka basai

Kāhā kāla, Kāhā kāla kā bāsā

Kāhā gyāna, Kābā gyāna kā musakalā

What is the citadel? What is its location?

Who are the people established in headquarters?

Who is it that trembles? Who is it that smiles?

How many does it take to uproot [the dwelling]? How many to settle it down?

What is time/death? What does time/death grab a hold of?

What is wisdom? What is it that makes wisdom shine?

After the questions follows the formulaic expression in red ink: ${ }^{21}$

kaihata kabīra suṇo guru Rāmānanda j̄̄

Says Kabīr, "listen, Reverend guru Rāmānand."

20 Throughout the text, he is referred to as asvāmi $\bar{\jmath} \bar{\imath}$ or guru jī (fols. 152r, 153v). There is also the formulaic kaibata rāmānandajī suno kabīra jī (fol. 151r).

21 This expression occurs also elsewhere in the text (fol. 152r). 
This is followed by what are marked as three separate lines (though only the first danda is marked in red):

Yā darīyyāva bharyā /

karìtī /

sataguru hoya saba tāvai /

This ocean is filled,

(with) praise

to the one who is the true guru of all.

One could debate whether "the true guru of all" refers to Rāmānand, but in bbakti texts it often stands interchangeably for God.

Then follows what seems to indicate the next speaker: putā (son). ${ }^{22} \mathrm{We}$ are led to understand this to refer to Kabīr, who addresses his interlocutor as "Guru Rāmānand," answering the latter's questions point by point:

kāyyā nagrī, baradā asathāna

mana rājā, pavana pradhāna

gyāna ka(m)pyai mana basai

Ajana vujada, Niranjana basai

Nìdrā kāla krodha kāla kā bāsā

Brama gyāna, sīla gyāna kā myānā

santoṣa gyāna kā musakalā

The body is the citadel. The heart is the location.

The mind is the king. The wind/breath [is established in]

headquarters.

Wisdom is what trembles. The mind is who smiles.

22 This putā occurs on other occasions (twice on fol. 151v, once on 152r, and twice on 154r), nearly each time just after a question and just before an answer. At one point in the text, the conversation partner is indicated also as kabīr jī (fol. 152v). 
Manuscript Studies, Vol. 4 [2019], Iss. 1, Art. 3

The undeserving uproot and the Absolute settles the dwelling.

Sleep is time/death. Anger is where time/death takes hold.

Brahma is wisdom. Virtue is wisdom's sheath.

Contentment is what makes wisdom shine.

This role division may surprise us in light of the hagiographic story, as there Kabīr came across as the one in search of wisdom, and Rāmānand as the fount of wisdom. In this text, most of the time it appears to be Kabīr answering the questions of the purported guru. ${ }^{23}$ One could surmise a teaching situation where Rāmānand is "quizzing" Kabīr, asking him questions in a standard format, perhaps not unlike Sufi interrogations of the "catechism" attested as early as the thirteenth century. ${ }^{24}$ Yet, there is never an issue of who does the questioning and who the answering there. We are not the only ones puzzled by this ambiguous situation.

\section{Edited Versions of the Dialogue}

How have editors of Gyān-tilak interpreted the dialogue between Kabīr and Rāmānand? The text was edited and published by the Nāgarīpracāriṇī Sabhā in Benares in 1955. Here it is understood as one of the "works of Rāmānand," as the title of the slim volume is Rāmānand kī Hind̄ Racnāen. In fact, the text is given twice within this volume, once in the main corpus of the work (pp. 12-16), and this is the best-known text, one could say

23 A similar confusion is also noted in connection with the dialogue between Kabïr and Gorakhnāth. See Bahadur Singh, "Problems of Authenticity in the Kabīr Texts Transmitted Orally in Rajasthan Today," in Images of Kabìr, ed. Monika Horstmann (New Delhi: Manohar, 2002), 196.

24 One of the disciples of Mu'în ad-dīn Chistī produced a very similar sounding work, Ușū aț-țaīqah. See Bruce Lawrence, Notes from a Distant Flute: Sufi Literature in Pre-Mughal India (Tehran: Imperial Academy of Philosophy, 1978), 36-37. Ironically, this type of questioning with rigid allegorical answers seems far removed from the transformative riddles found elsewhere in Kabīr's poetry, on which Linda Hess has eloquently written in her "The Cow Is Sucking at the Calf's Teat: Kabir's Upside-Down Language," History of Religions 22, no. 4 (1983): 313-37. 


\section{Pauwels: Power Permutations in Early Hindi Manuscripts}

the vulgate. For instance, it served as the basis of the sole translation of the work in Italian produced by the University of Turin scholar Pinucchia Caracchi in collaboration with the respected Banaras Hindu University Hindi scholar Shukdev Singh. ${ }^{25}$ This edition of the text was prepared by the aforementioned Hindi scholar Pītāmbar Datt Baṛthvāl before his passing in 1944. His work was then seen to publication by Hazārīprasād Dvivedī, under whose direction a second version of the text with significant permutations was included in appendix 2 (pariśisța). ${ }^{26}$ All scholarship on this topic is deeply indebted to these careful and formidable scholars of Hindi literature, on whose shoulders we are fortunate to stand to understand better this difficult literature. It appears, however, that there are major differences between the two edited texts that we need to understand to evaluate their meaning.

In Barthvāl's version, the text of the Gyān-tilak proper is preceded by several philosophical verses on the process of creation that evoke Kabīrdās as a listener in the last line (v. 12 on p. 12). This is followed by a group of stanzas, the last of which also refers to Kabīrdās. The Gyān-tilak proper is then introduced by the following lines:

Aba kī bera mobi bakasalyau kadama dāsa kabīra

Gura rāmānanda ke badana pai sadaka karūm sarīra

Svāmī jī tumba satagura hama dāsā . . .

pūchūm eka sabada kā bheva, karo krpā kabo gura deva (GT1: vv. 1-2)

This time, please grant me [a place at] your feet, [says] the servant Kabīr

For the words of guru Rāmānand, I would surrender my body.

Reverend Svāmī, you are the true guru and I am the servant . . .

May I ask the secret of one of your utterances, please be merciful and tell me, Lord Guru.

25 Rāmānanda e lo yoga dei sant (Alessandria: Edizione del'Orso, 1999).

26 In the preface, Dvivedī says he worked with the help of Daulat Rām Juyāl and Bhuvaneśvar Gaud. The appendix is on pp. 31-37. 
Manuscript Studies, Vol. 4 [2019], Iss. 1, Art. 3

With such a humble introduction of Kabīr, the reader is naturally led to understand that the following verses (3-6) with the questions that constitute the beginning of the Gyān-tilak proper would be asked by Kabīr and might assume the introductory hypermetrical word svāmi $\bar{j} \bar{\imath}$ (given between parentheses in the edited text and not preceded by the demonstrative pronoun) would be a vocative, addressing Rāmānand:

(Svāmī jì) kauna sī nagarī, kauna asthāna, kauna loga basain paradhāna (Reverend Svāmī) what is the citadel, what is the location, who are the people dwelling in headquarters?

This impression is strengthened by the printed edition's visually grouping the questions together, and concluding the last couplet with the phrase kabaị̀ kabìra guru Rāmānanda jī yaba dariyāva bharā kai rìtā (v. 6), which is similar to what we saw in the manuscript, except that the vowels of the final word are different, notably a diphthong for the first vowel (kariti becomes kai rìt $\bar{a}$ ), and the word is split up; thus the first part, kai, becomes the question word, and the second, rìtā, is an adjective meaning "empty." The full line then comes to mean, "Says Kabīr: Reverend Guru Rāmānand, is this ocean full or empty?"

In addition, the next set of verses that provides the answer to each of the questions in turn is introduced by suno sidha ("Listen, oh siddha"; without parentheses, thus regularized as part of the verse). In this edition, this vocative is again portrayed as the beginning of the allegorical answer by integrating it in the first line:

Suno sidhā kāyā nagarī brdaya asthāna

Pāñca loga basain (pradhāna) mana rājā pauna pradhāna

Listen, oh yogi, the body is the citadel, the heart is the location.

Five people dwell (in the capital) the mind is the king, the breath is foremost.

The revelation continues along similar lines as in our manuscript (with significant variants), ending with: 
Kabīra suno sabada kā bheva, hrdayā basam nirañjana deva Kabìra jī ye lyau nagarī kà bheva

Listen Kabirr, to the secret of the word, when the Absolute dwells in the heart.

Kabīr jī, take this to be the secret of the citadel.

In Barthwal's redaction, then, Kabìr is the one asking the questions, and Rāmānand the one answering. Reading on, the situation becomes somewhat confused as to who is asking the questions and who is answering, but clarity returns; for instance, midway through the text the aforementioned formulaic expression occurs a second time, with a small permutation, and this time appears within parentheses, suggesting it is hypermetrical:

Japa karam tapa karam koți tīratha bbrama āvain (kabai kabìra suno guru Rāmānanda jī) jugati bina jogesvara kasa kari parama pada pāvai (v. 28)

Reciting rosary, performing asceticism, coming back from hundreds of pilgrimages,

(Says Kabīr, listen Reverend guru Rāmānand:) without uniting with the Lord of yoga, how could one reach the highest realm?

In light of the previous line, the last one could be a rhetorical question, contrasting traditional pious-works-oriented religiosity with union with God. However, through the insertion of the speaker, Kabìr, and his appeal to the guru, it is turned into a real question. This intervention is strategically placed so that if the reader were confused about who is saying what, this would help get him back on the track laid out earlier-that is, interpreting Kabīr as asking questions and Rāmānand as providing answers. The last verse confirms this once again:

Agama nigama bai pantha hamārā sāșā āra (patra) amī rasa pìy $\bar{a}$ Suno kabira jī so jogesvara juga juga jīyā (v. 58) 
Manuscript Studies, Vol. 4 [2019], Iss. 1, Art. 3

Our path is hard and difficult to reach, ${ }^{27}$ branch and leaf ${ }^{28}$ have absorbed the nectar of immortality.

Listen, Kabīr, the Lord of yoga has lived aeon after aeon!

In sum, this vulgate Gyān-tilak casts Rāmānand as the wise man imparting his secrets of wisdom to Kabīr. Through editorial interventions, such as the visual arrangement of the verses, the bracketing within parentheses (or not) of the conversation partners, and the recasting of statements as questions, this dialogue has acquired a definite hierarchical structure in favor of Rāmānand as guru and Kabīr as disciple. Perhaps this is natural given the editor Baṛthwāl's view of the important role Rāmānand plays in the great Indian heritage of bbakti, which he expressed elsewhere in his works. ${ }^{29}$ Barthwāl felt strongly that the new nation needed the "Nirguna School" (8-9) with its "harmonious blending of practically all that is good in the Indian spiritual thought," including "the practice of Yoga . . , the monism of Śankarācārya, the doctrine of Grace, the sensuous intensity of the passion of devotion" (xii). While Kabīr may have articulated this best in his strident poetry, the inspiration came from Rāmānand, to whom goes the credit of combining devotion with earlier strands like the yoga of the Nāths and the prestigious philosophy of the Sanskrit tradition based on the Upanișads in a coherent system of thinking (esp. pp. xiii-xiv). Not coincidentally, this repudiated the need for crediting bbakti's critique of caste and iconoclasm to Islam and its spirituality to Sufism. Even though it was hard to deny, given his name, that Kabìr may have been influenced by Islam, the Hindu nationalists' narrative could neutralize this because his guru taught him the essence based purely on Hindu sources. Barthwāl had proudly announced his discovery of Rāmānand's works that confirmed the guru's important position in formulating the new spirituality (xvi). Naturally he

27 This is how Pinucchia Caracchi translates it, but she remarks in her notes that this may also be an assertion that the path is orthodox, i.e., based on Āgama and Nigama texts (Rāmānanda e lo yoga dei sant, 348-49.

28 It is unclear here why the parentheses were used. I presume that it is a correction of the reading of the previous word as āra, which makes little sense.

29 He articulates this clearly in the preface of his Traditions of Indian Mysticism. 


\section{Pauwels: Power Permutations in Early Hindi Manuscripts}

would be inclined to read the Gyān-tilak as Rāmānand's instruction to Kabìr rather than the other way around.

We should be careful, though, not to ascribe this approach wholesale to editorial intervention: Baṛthwāl based his edition on a manuscript preserved in the Âryabhāṣā Pustakālay collection of the Nāgarī Pracāriṇī Sabhā in Benares. According to the catalogue, the Gyann-tilak manuscript preserved in this collection was written in 1809 in Rāmkot in Ayodhya. ${ }^{30}$ This text came from a sectarian corner from the Rāmānand-sampradāy, so it would be natural to portray Rāmānand, the guru, as superior.

Let us turn now to the second version of the dialogue in the appendix to the same edition of Rāmānand's works. This one, prepared after Barthwāl's passing by Dvivedī's team, is different. In this version, clearly, it is Svāmī jī who asks the questions, and Kabīr who provides the answers, which are introduced and prominently set off on a separate line with the Sanskritic-sounding Kabira uvāca. This version also contains a (somewhat different, though there is some overlap) philosophical introduction by Kabīr about creation (pp. 31-32), before the Gyān-tilak proper starts (at the middle of p. 32). This, however, is presented as in response to a question by Rāmānand, whose question opens the work in this version; he seeks to know the basis of creation, and Kabìr's lofty answer starts with anabad, "the unstruck sound," thus giving this yogic Nāth concept pride of place.

The appendix's Gyān-tilak proper (32-37) overlaps significantly with the vulgate, but apart from the switch in role of the interlocutors, the verses also appear in a different sequence, with multiple permutations, the significance of which merits closer study. Suffice it for our purpose to emphasize that the interrogator is nearly consistently svāmijiz and the answers are provided under the lofty rubric kabìra uvāca ("Thus spoke Kabī").

It should be said that while Kabīr has gained (or retained) the upper hand in the conversation, Rāmānand is emphatically confirmed as Kabīr's guru in the last line:

30 This manuscript (vol. 1, no. 279/859), dated 1866 VS, starts with the invocation (mañgalācāraṇ) Shrī Rāmānujāya namah. 
Manuscript Studies, Vol. 4 [2019], Iss. 1, Art. 3

Haṃsā choda sarovara kabīm na jāya, bhagata sarīī upaj̄̄ Pāyā pada nirabāna

Guru rāmānam da ke bacana para sabda kā karo paramāna

Niraguna guru saraguna celā guru rāmānanda som bāla buā melā

The swan does not leave the holy lake: the devotee emerged bodily and obtained the highest state.

By means of Guru Rāmānand's words, prove the validity of [these] words.

The guru['s God] is above qualities, the pupil['s] is marked by all qualities. The child (Kabīr) met with guru Rāmānand.

The ambiguity of the Kabīr-Rāmānand relationship, then, is foregrounded here. In this specific configuration of the dialogue, it seems that Kabīr, the nirguna representative, instructs Rāmānand, the saguna one. Still, at the end it is explicitly confirmed that Kabīr as a child took initiation from guru Rāmānand.

Similarly, the colophon seems to ascribe the text to dual authorship:

Iti śrī guru rāmānanda kabìra kā jñāna tilaka sampūraña

Thus is completed the "Mark of Wisdom" by Holy Guru Rāmānand [and] Kabīr.

This appendix version, transcribed by a different editor, is based on a different manuscript, which was preserved in the private collection of Uday Śankar Sāstrī. ${ }^{31}$ It is related to the one in the next appendix (parišisț 3, pp. 38-48), which is a work attributed to Rāmānand's guru Rāghavdās. Rāghavdās is considered to have forged a balance between yoga and bhakti. ${ }^{32}$ This confirms a favorite theme of Hazārīprasād Dvivedìs, which he shared with Baṛthwāl—namely, that Kabīr's significance lies in intermediating the

31 This is probably the same manuscript that is the basis of the three preceding works in the appendices (Mānasī Sevā [Spiritual Worship], Gyān-līlā [Wisdom's Play], Ātma-bodh [Illumination of the Self]).

32 Similarly, Appendix 4 contains a work of Rāmānand that reconciles yoga and bhakti. 


\section{Pauwels: Power Permutations in Early Hindi Manuscripts}

yoga legacy of Gorakhnāth and the Nāth yogīs. ${ }^{33}$ Rāghavdās's text here is offered on the basis of a manuscript that the editor carefully demonstrates to be a seventeenth-century polemical text of one sub-branch that sought to promote the position of Kabīr in the Rāmānand-sampradāy. ${ }^{34}$ While the editor does not explicitly link it to the Gyān-tilak text, one could well consider this assessment content-wise pertinent for the other manuscript too.

In connection with the interrelation between Nāth yogis and Sants, it should be pointed out that there is a related work, also called Gyan-tilak, that is attributed to Gorakhnāth, who is frequently seen as the founder of the Nāths. This work was included in the Baṛthwāl edition cum Hindi explanation of Gorakh's collected works. ${ }^{35} \mathrm{He}$ based it on three manuscripts, one undated Sanskrit version and two others 1768 (1825 VS), and 1798 (1855 VS) from Jaipur collections (pp. 12-14). There are other (Dādūpanthī) manuscript versions, but all later or undated. ${ }^{36}$ The content of this work has a few related stanzas, but on the whole it is quite different. For our purpose, it is most pertinent that the interlocutor of the Rāmānand-Kabīr version is also addressed as sìdha a a term commonly used for Nāths. It is outside the scope of this article to compare the Jũan-tilak texts to establish these different sectarian approaches to the same literature. It suffices here to note that Gorakh's text is not in question-and-answer format, and no interlocutors are indicated. Therefore, this text is not really a dialogue, but rather an exposition of the guru's understanding of secret knowledge addressed to his disciples.

33 See J. S. Hawley, A Storm of Songs: India and the Idea of the Bhakti Movement (Cambridge, MA: Harvard University Press, 2015), 50-51. For Dvivedī, this was only the first stage of Kabïr's life before the conversion by Rāmānand, as noticed by J. S. Hawley in Three Bhakti Voices (New Delhi: Oxford University Press, 2005), 328.

34 He obtained it from the Hanumān temple in Govardhan, whose mahant was a Rāmānujī sādhū named Rāmśaraṇdās (40-41).

35 Gorakb Bānī, 2nd ed. (Prayāg: Hindī Sāhitya Sammelan, 1947), 207-20.

36 A Hindi version attributed to Gorakhnāth, written in 1884, is preserved in the Dr. B.R. Ambedkar Viśvavidyālay, Agra, acc. no. 1020.1 (42 fols.). A Sanskrit version attributed to Gorakhnāth is preserved in the Jawaharlal Nehru Library, Baba Mastnath Ayurvedic College, acc. no. R 98 (3 fols.). An undated manuscript is also preserved in the Rajasthan Oriental Research Institute, Jodhpur collection according to the catalogue, vol. 1, p. 58, no. 148 (20). 
Manuscript Studies, Vol. 4 [2019], Iss. 1, Art. 3

\section{Historical Background of the Editions}

The published versions of Rāmānand's dialogue with Kabīr have to be evaluated against the background of specific views the nationalist editors held on the role that bbakti could play to unify and strengthen the new nation. Ironically, the iconoclastic Kabīr is seen as a bridge-builder, reconciling yoga and devotion, which received Rāmānand's orthodox stamp of approval and was carefully kept separate of Islamic influence. There is, however, more to the issue than the nationalist-communalist context. We should keep in mind the contentious climate of the Rāma devotional groups early in the twentieth century. At this time, an infra-sectarian break was forced by a radical Rāmānandī faction that had sought to eliminate all links with the Rāmānuja mother-sampradāy and to completely abolish caste-based distinctions. Ironically, this was accomplished through Sanskritizing Rāmānand himself and neglecting the Hindi works attributed to him. ${ }^{37}$ In the process of producing evidence for their claims, the interested parties used a discourse of textual criticism and archeology in which archival retrieval, in particular the "discovery" of manuscripts, played a major role. In contrast to this polemic, the carefully reasoned edition of Rāmānand's works by Baṛthwāl and Dvivedī may represent a scholarly countermove to reinscribe Rāmānand as a charismatic Hindi teacher, once again coopting the vernacular appeal of Kabīr, but in this case for the nationalist movement and, for Dvivedī, to establish bhakti's "indigenous" nature, obliterating the need for acknowledging Islamic influence. ${ }^{38}$ Thus they succeeded in changing the narrative of the bhakti movement's contribution to Hindu nationalism: in contrast to Rāmcandra Śukla's earlier privileging of Rāma and Krishna saguna literature over the nirguna saints deemed unsophisticated

37 This was spearheaded by Bhagvad Dās, later named Bhagvad Ācārya. See the revealing work of Purușottam Agrawal, especially his online article "In Search of Ramanand," in Pratilipi, esp. pp. 5-7 (http://pratilipi.in/in-search-of-ramanand-purushottam-agrawal/5/). Also see Pinch, Peasants and Monks, esp. chapter 2.

38 Monika Horstmann stresses that Dvivedī viewed Kabīr as an ideal man, evolving toward a spiritual view thanks to the intervention of his guru, much as Dvivedī himself was transformed in his meeting with Rabindranath Tagore (Horstmann, "Hazārīprasād Dvivedī’s Kabīr," 120-22). 


\section{Pauwels: Power Permutations in Early Hindi Manuscripts}

and influenced by Islam, the latter now were rehabilitated as indigenous providers of answers for the new nation's needs. ${ }^{39}$

\section{Däduppanthī Context of the Manuscript}

Similarly, we need to situate the Wellcome manuscript in its historical context. The clues provided by the colophon quoted above, namely the time of King Savāì Jai Singh II and the place-namely, the Rajasthani village Naraina-are very helpful. Naraina is a major seat of the Dādūpanthīs, a sect looking to the late sixteenth-century cotton-carder saint Dādū Dayāl for its origins. ${ }^{40}$ At the time the manuscript was written down in 1715 , the Mahant, or “abbot," in Naraina was Jaitrām (d. 1732), who was the first Brahmin head of the seat. He worked to establish his authority through an attempt to "clean up" the many divergent and idiosyncratic factions within the sect, which has been documented in the account of his abbotship, Jayatprakāss (The Light of Jait[rām]). ${ }^{41} \mathrm{He}$ did so notably with regard to commensuality rules, but also in connection with ritual exchanges between guru and disciple. ${ }^{42}$ The manuscript's focus on images of guru-disciple pairs, one of which features Dādū with his disciple, the singer Sundardās

39 Hawley, Storm of Songs, 44-45.

40 For a good succinct introduction, see Monika Horstmann, "Dādū Dayāl," in Encyclopedia of Hinduism, ed. Knut A. Jacobsen, Helene Basu, Angelika Malinar, and Vasudha Narayanan (Leiden: Brill, 2012).

41 The text was authored by Jñāndās. Only one chapter of this lengthy hagiography has been published as Panth-paddhati. Details of the manuscript sources are unknown, but the text was definitely written before 1827 . It has been translated and studied by Monika Horstmann, "The Flow of Grace: Food and Feast in the Hagiography and History of the Dādūpanth," Zeitschrift der Deutschen Morgenländischen Gesellschaft 150, no. 2 (2000): 546-47. She corroborates the evidence with reference to other sources, in particular documents from the Naraina archives.

42 For commensurality rules, see Horstmann, Der Zusammenbalt der Welt: Religiöse Herrschaftslegitimation und Religionspolitik Mahārājā Savā̄ Jaisinghs (1700-1743). (Wiesbaden: Harrassowitz, 2009), 173. For the ritual exchanges, see Horstmann, "The Flow of Grace," 546-47, on the basis of the document Panth-paddbati (written before 1827), of which she provides a translation and commentary, corroborating with other sources, in particular documents from the Naraina archives. 
Manuscript Studies, Vol. 4 [2019], Iss. 1, Art. 3

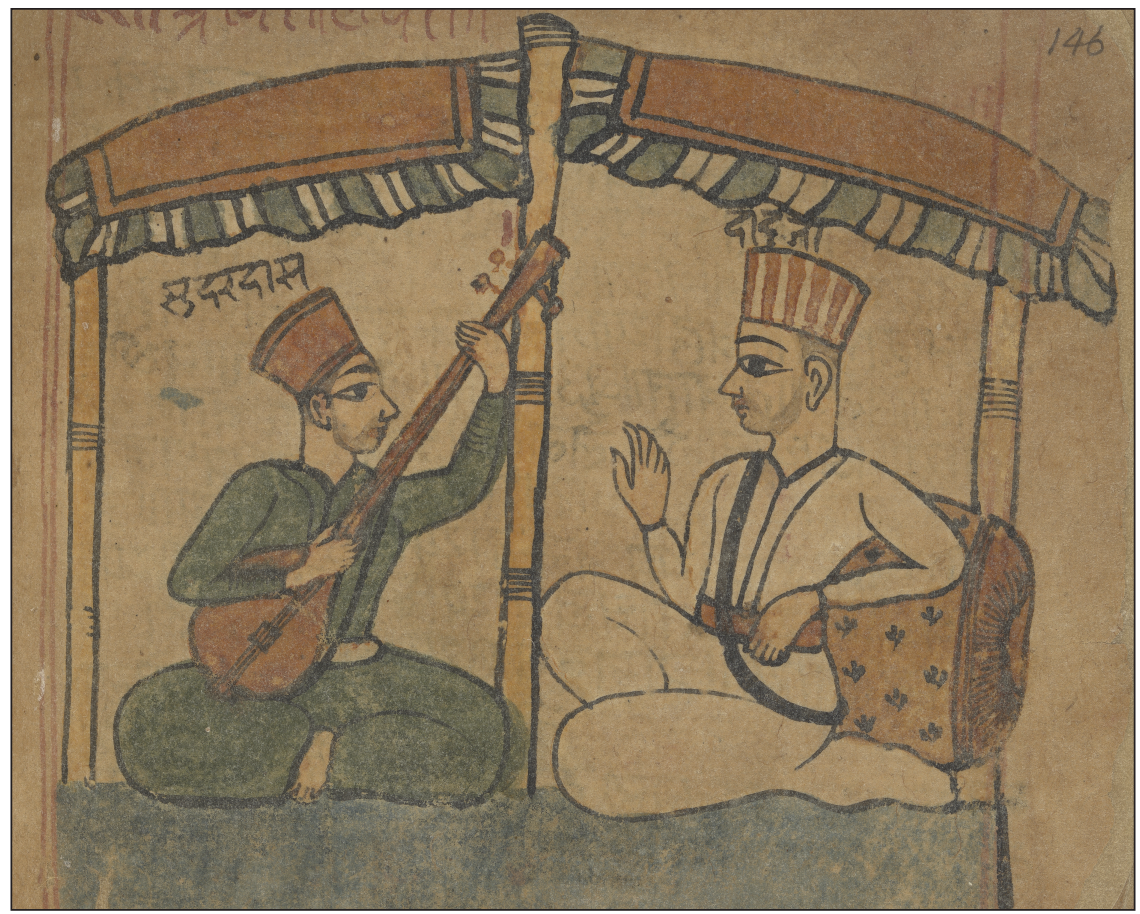

FIGURE 4. Sundardās and Dādū in conversation. Wellcome Collection, MS Hindi 371, fol. 146r.

(fol. 146r; fig. 4), fits well with the abbot's preoccupations at the time. ${ }^{43}$ It is not unlikely that Sundardās's compositions became part of the Dādūpanthī lithurgy at exactly this time. ${ }^{44}$ The Jayat-prakās articulates the obligation for Dādūpanthīs to collect the words of the Sants and carry those with them, which constitutes an immediate imperative for the writing of manuscripts, such as this one. ${ }^{45}$

At the same time, Jaitrām was trying to coopt and stem the tide of growing influence of the sadbus of Rajput origin, who had formed the Nāga

43 Friedlander, Descriptive Catalogue, 602.

44 I am grateful to Monika Horstmann for pointing this out (personal communication, 6 January 2018).

45 Horstmann, “The Flow of Grace," 548. 


\section{Pauwels: Power Permutations in Early Hindi Manuscripts}

or warrior faction. As mercenary troupes, the Nāgās were operating under a different economic regime than the sadbus, who had vowed monastic poverty. These militant orders had become increasingly powerful and keen to assert their independence from the abbot. ${ }^{46}$ They refused to follow the Mahant's directions to become clean-shaven and asserted their own warriorlike identity. ${ }^{47}$ In his efforts to establish his authority, Jaitrām was supported by another faction, the Utarādhās, or disciples from "the North" - that is, from Haryana and Punjab. This monastic business community had been heavily influenced by the Sikh model from the Punjab, and hence was involved in the building of Dādūpanthī gurudvārās and probably responsible for introducing the term Khālsā (for a faction in the Dādūpanth, now distinguished by dressing in white and wearing caps). ${ }^{48}$ One wonders whether their influence is behind inclusion in the Wellcome Institute manuscript of the illustration of Guru Nānak (the first Sikh guru) in dialogue with a disciple identified as Harirāy (fol. 188v; fig. 5). ${ }^{49}$

The Dādūpanthīs in general and the Nāgās in particular were subject to the influential reforms pushed through by Savāì Jai Singh II, the king and founder of nearby Jaipur, who is mentioned by name in the manuscript's colophon. He urged all bhakti communities to conform socially with orthodoxy (compliance with varnāśrama-dharma), theologically with the four recognized bbakti sects (catub-sampradāya), as well as militarily by establishing recognized orders of warrior ascetics ( $\bar{a} k b \bar{a} d \bar{a} s)$. In 1733, several Dādūpanthī sadbus signed a document to the effect that they would comply with Jai Singh's stipulations, including the prohibition for non-Brahmins to become abbots. ${ }^{50}$ In 1756 , furthering Jai Singh II's project, the influential

46 Horstmann, "The Flow of Grace," 538-39.

47 James M. Hastings, "Poets, Sants, and Warriors: The Dadu Panth, Religious Change and Identity in Jaipur State Circa 1562-1860,” Ph.D. Dissertation, University of WisconsinMadison, 2002, 46.

48 See Horstmann, “The Flow of Grace," 544-45.

49 Friedlander, Descriptive Catalogue, 601. This may be an anachronistic, imagined dialogue with the seventh Sikh guru, who died in 1675 .

50 The document is translated by Monika Horstmann in "Ein Kapitel nordindischer Religionspolitik im 18. Jahrhunert: Jaisingh II. Und die religiösen Orden,” Zeitschrift für Religionswissenschaft 2, no. 1 (1994): 49-67. 
Manuscript Studies, Vol. 4 [2019], Iss. 1, Art. 3

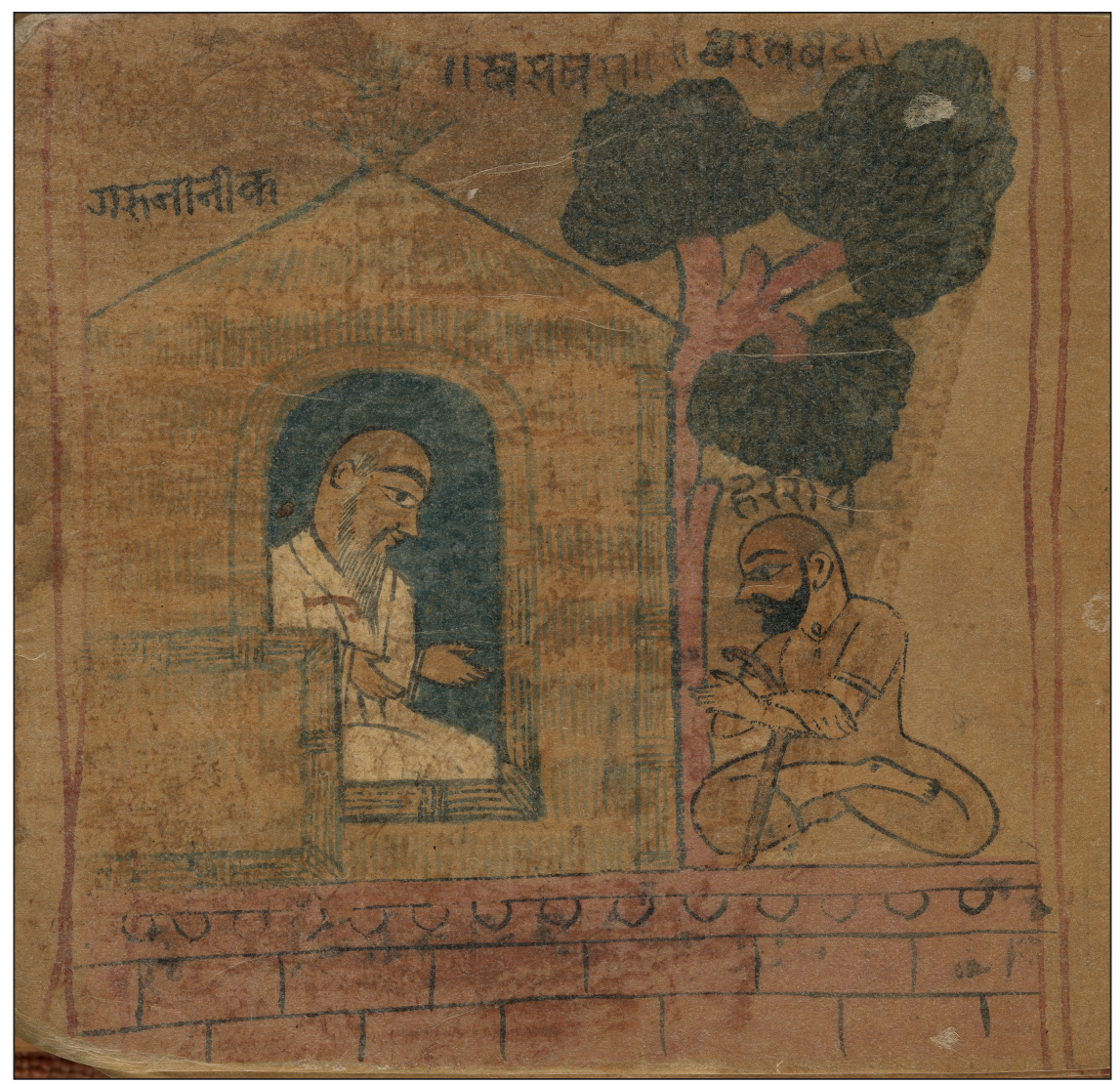

FIGURE 5. Guru Nānak and Harirāy in conversation. Wellcome Collection, MS Hindi 371, fol. $188 \mathrm{v}$.

Rāmānandī abbot Bālānand organized different bands of warrior ascetics in officially approved $\bar{a} k b \bar{a} d \bar{a} s$. At that time, he tried to bring the Dādūpanthīs under his influence, seeking a merger with his own Rāmānandī sect. While hardly conclusive, this slightly later context is suggestive. One wonders whether the manuscript's attention to boost Kabīr's position versus Rāmānand's is an early reflection of such power struggles between the Kabīrchampioning Dādūpanthīs and the more orthodox-inclined Rāmānandīs at the time of Jai Singh. 


\section{Conclusion}

We see that the dialogue between Kabīr and Rāmānand is redacted in many different ways: different manuscripts frame similar texts with different permutations, and so, it turns out, do the printed editions. Perhaps the transition from manuscript culture to print is not as radical a rupture as it is sometimes made out to be.

How to fathom this phenomenon of the multiple framings of the Early Hindi debate between Kabīr and Rāmānand? Perhaps we can turn to the visual arts for a parallel. A common technique in Indian painting was to copy details of successful painting compositions and transfer them into a new one, by tracing the master drawing on a thin vellum (charba) that was pierced along the outlines with a fine needle. ${ }^{51}$ Such "models" could be reused in different contexts to fit a different frame. Similarly, copies of existing paintings could be bound together in new contexts for a different patron with his own predilections, in particular in albums called muraqqa' or patchwork. ${ }^{52}$ Art historians have argued that rather than seeing such work as derivative and search for the original, it has to be valued in its own context. ${ }^{53}$ Thus, to give an example relevant for our topic, there is a detail portraying Kabìr and the Sants from the border of an image "Dance of the Derwishes" depicting ecstatic Sufis dancing in Ajmer, most likely produced in Dara Shikoh circles in the mid-seventeenth century (fig. 6)..$^{54}$

51 See, e.g., Percy Brown, Indian Painting (London: Oxford University Press, 1920), 103-4.

52 See Elaine Julia Wright and Susan Stronge, eds., Muraqqa' Imperial Mughal Albums from the Chester Beatty Library, Dublin (Alexandria, VA: Art Services International, 2008).

53 See, for instance, the extended study of the Lailah and Majnun theme as depicted in Rajasthani paintings in Molly Aitken, The Intelligence of Tradition in Rajput Court Painting (New Haven, CT: Yale University Press, 2010), 154-209.

54 Elinor W. Gadon, "Note on the Frontispiece," in Karin Schomer and W. H. McLeod, eds., The Sants: Studies in a Devotional Tradition of India (Delhi: Motilal Banarsdass, 1987), 415-21. The painting can be viewed on the V\&A website at http://collections.vam.ac.uk/ item/O16063/khwaja-sahib-painting-unknown/. 
Manuscript Studies, Vol. 4 [2019], Iss. 1, Art. 3

Pauwels, Power Permutations in Early Hindi Manuscripts

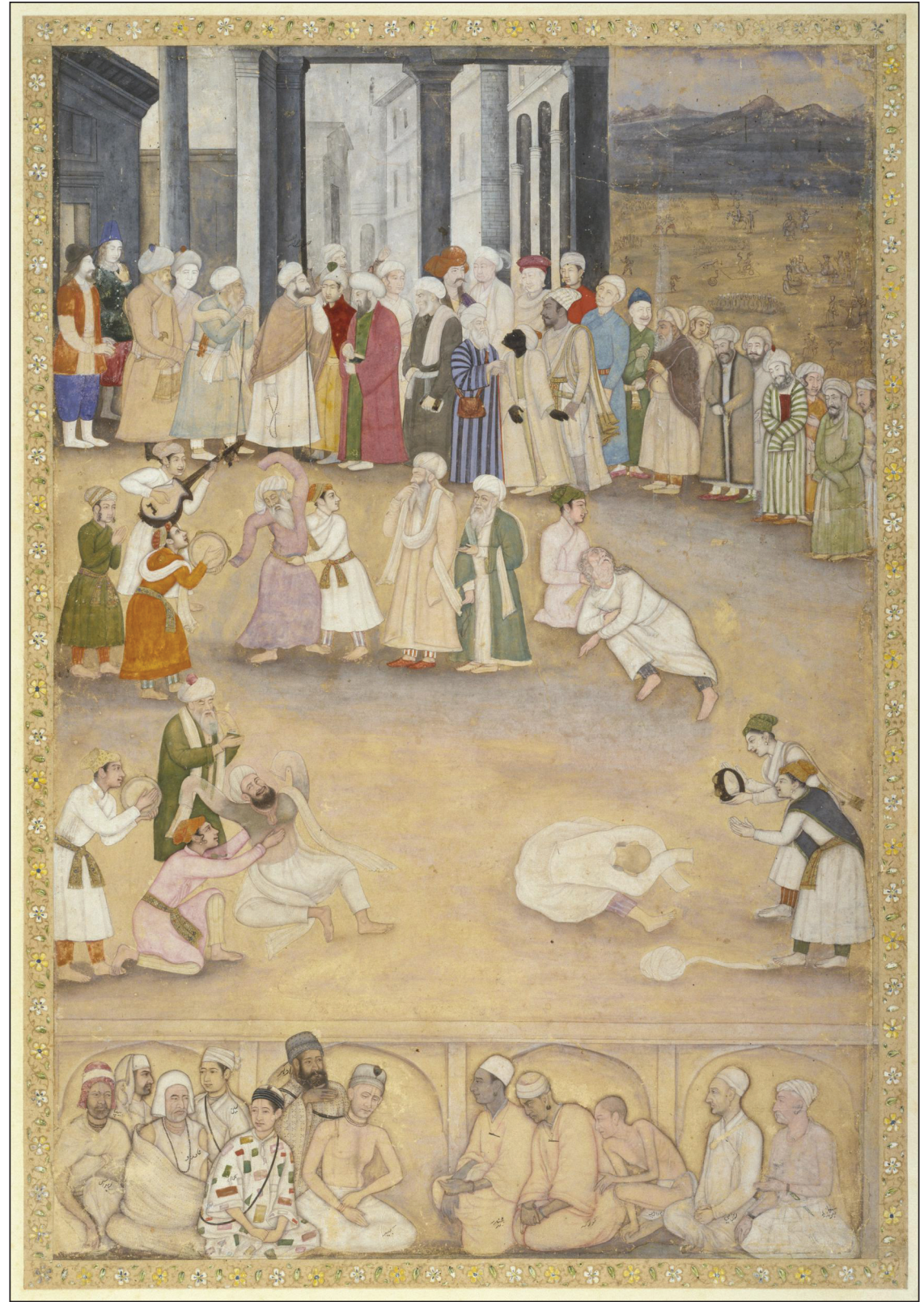

FIGURE 6. The Sants. Victoria \& Albert Collection, detail of 016063 “Khwaja Sahib.” (C) Victoria and Albert Museum, London. 
This image was lifted out of context, copied by Mir Kalan Khan circa 1770, and projected against the backdrop of a hut (fig. 7). ${ }^{55}$ Rather than dismissing this second work as a mere copy, it would pay off to study the processes involved in this transfer and inclusion of the image in an album for a different patron.

The albums involved mounting and stitching of images, hence the name Muraqqa' or patchwork. Incidentally, the cloak of many derwishes and holy men is also made of such patchwork, as seen in the garb worn by Kabir's son, Kamal, in the painting. The figure of Kamal is in turn lifted out of the painting and combined with that of Dara Shikoh in another image. ${ }^{56}$ This practice of recycling images can be a metaphor for what we see happen to dialogic texts in print and manuscripts alike. Behind the printed page emerges a historically layered picture to reveal a kaleidoscopic arrangement of debates: never settled, always refracted anew.

55 The image is now in the Metropolitan Museum of Art on view in gallery 463, acc. no. 2009.318. See Maryam Ekhtiar, Sheila R. Canby, Navina Haidar, and Priscilla P. Soucek, eds., Masterpieces from the Department of Islamic Art in the Metropolitan Museum of Art (New York: Metropolitan Museum of Art, 2011), no. 253, pp. 341, 363-64, ill. p. 363 (color). It is also online at https://www.metmuseum.org/art/collection/.

56 Now in British Library (J.19, 1). See J. P. Losty, “Ascetics and Yogis in Indian Paintings," British Library website, 15 August 2016, http://blogs.bl.uk/asian-and-african/2016/08/ ascetics-and-yogis-in-indian-painting.html. 
Manuscript Studies, Vol. 4 [2019], Iss. 1, Art. 3

Pauwels, Power Permutations in Early Hindi Manuscripts

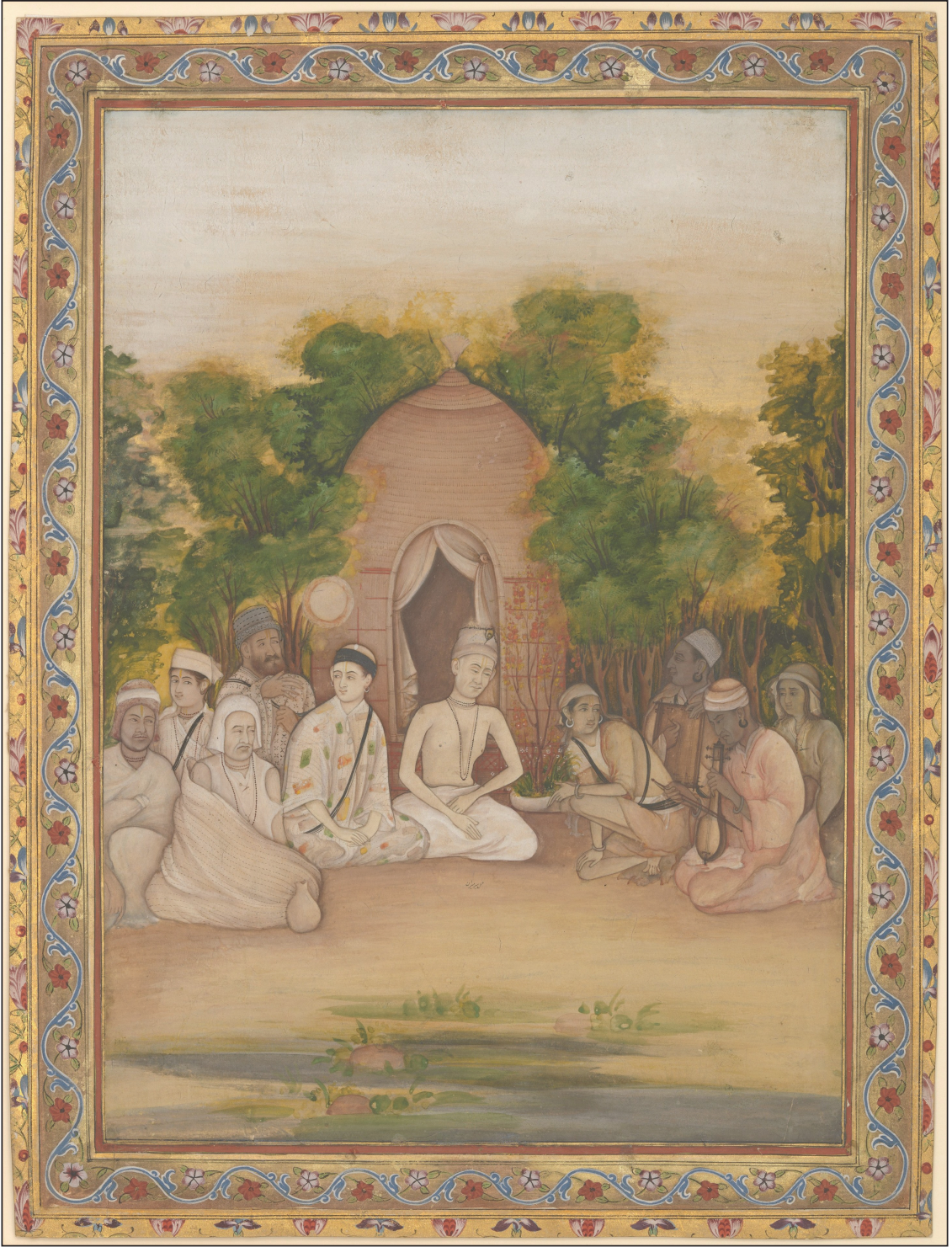

FIGURE 7. A Gathering of Holy Men of Different Faiths by Mir Kalan Khan, ca. 1770-75. Metropolitan Museum, acc. no. 2009.318. 